\title{
Serratia fonticola, a New Species from Water
}

\author{
F. GAVINI, ${ }^{1}$ C. FERRAGUT, ${ }^{1}$ D. IZARD, ${ }^{1}$ P.A. TRINEL, ${ }^{1}$ H. LECLERC, ${ }^{1}$ B. LEFEBVRE, ${ }^{2}$ aND \\ D.A.A. MOSSEL ${ }^{3}$ \\ Institut Pasteur de Lille, Institut National de la Santé et de la Recherche Medicale, U 146, Domaine du \\ Certia, BP 15 France $^{1}$; Université de Lille I, Institut Universitaire de Technologie, Cité Scientifique, 59650 \\ Villeneuve d'Ascq, France ${ }^{2}$; and Chair of Medical Food Microbiology, University of Utrecht, 3572 BP \\ Utrecht, The Netherlands ${ }^{3}$
}

\begin{abstract}
Twenty strains of Enterobacteriaceae isolated from water are assigned to a new species in the genus Serratia on the basis of phenetic (numerical analysis) and genetic (deoxyribonucleic acid [DNA]-DNA hybridization) evidence. They are closely related to each other (75 to 91\% DNA-DNA relatedness) and show $50 \%$ DNA relatedness with species of Serratia but only 20 to $30 \%$ relatedness with other members of the family Enterobacteriaceae. The strains are acetoin, gelatinase, and deoxyribonuclease negative, but lysine, ornithine decarboxylase, and Tween-esterase positive. They are metabolically very active, fermenting all the sugars and alcohols tested except melezitose, inulin and sorbose. The name Serratia fonticola is proposed for these strains. Strain 11 (= ATCC 29844) is the type strain of the species.
\end{abstract}

In 1965, Leclerc and Buttiaux (18) described a new group of Enterobacteriaceae which seemed related to the genus Citrobacter on the basis of its IMViC characters (indole positive, methyl red positive, Voges-Proskauer [acetoin] positive, Simmons citrate positive) but which differed from Citrobacter in other significant properties such as lysine decarboxylase production.

In a recent numerical taxonomy study (12), we confirmed the relationship of these strains to each other. Crosa et al. (3) and subsequently Steigerwalt et al. (25) in a deoxyribonucleic acid (DNA)-DNA hybridization study established that this group of "Citrobacter-like" bacteria, referred to as "class C," are more closely related to Serratia than to Citrobacter or any other Enterobacteriaceae.

Taking this into account, we carried out another numerical taxonomy study with the strains of class $\mathrm{C}$ and strains of Serratia, including type and neotype strains. Moreover, we evaluated the genetic relatedness of the class $C$ strains through DNA-DNA hybridization and assessed the rate of relatedness of the class $C$ reference strain with serratiae (S. marcescens, S. liquefaciens, S. plymuthica, and $S$. rubidaea). Finally, we have attempted to determine the taxonomic position of the class $\mathrm{C}$ strains.

\section{MATERIALS AND METHODS}

Bacterial strains. The phenetic study included 72 strains isolated from water and soil (20 of them cluster in the previously defined class C) and 20 Serratia strains from culture collections (Table 1).
The DNA-DNA hybridization studies were carried out with the following strains: 15 class $\mathrm{C}$ strains, 3 strains representative of class $C$ as defined in the numerical taxonomy study, and 32 culture collection strains of the family Enterobacteriaceae (see Table 5).

Biochemical tests. The biochemical tests used were described previously $(11,12)$.

Numerical analysis. After elimination of the characters which were positive or negative for all of the strains, the remaining characters (117 of 219) were analyzed. Similarity between strains was calculated by means of the DICE index (11). Classification of the strains was based on the hierarchical aggregation method, using average distance (4).

DNA-DNA hybridization. DNA extraction was performed by Marmur's method (21) as slightly modified by Ferragut and Leclerc (9).

The purity and quality of each DNA preparation were checked by determination of the absorbancy ratio at $260 / 280 \mathrm{~nm}(1.8$ to 1.9$)$ and at $260 / 230 \mathrm{~nm}(2.0$ to 2.3) (according to Marmur [21]) and by the melting $\left(T_{m}\right)$ curves, which include hyperchromicity values from 30 to $40 \%(9,20)$.

The strain chosen for DNA labeling was the reference strain of class $C$ (strain 11). For the preparation of labeled DNA, $1 \mathrm{mCi}$ of $\left[{ }^{3} \mathrm{H}\right]$ thymidine (specific activity, 10 to $25 \mathrm{Ci} / \mathrm{mmol}$; Centre Energie Atomique, Gif sur Yvette, France) was added to $500 \mathrm{ml}$ of a synthetic medium containing $4 \mathrm{~g}$ of glucose per liter, $4 \mathrm{~g}$ of Casmino Acids per liter, and $250 \mu \mathrm{g}$ of deoxyadenosine per liter to inhibit the thymidylate synthetase. The cells were harvested in the late log phase. The specific activity was $80,000 \mathrm{cpm} / \mu \mathrm{g}$ for ${ }^{3} \mathrm{H}$-labeled DNA. The unlabeled DNA of high molecular weight was fixed and denatured on nitrocellulose filters by the technique described by De Ley and Tyjtgat (5).

Fragmentation of unlabeled and labeled DNA was 
carried out in a French pressure cell (10) at a pressure of $20,000 \mathrm{lb} / \mathrm{in}^{2}$.

DNA-DNA reassociation was done in a doublestrength citrate salt solution (SSC; $0.15 \mathrm{M} \mathrm{NaCl}-0.015$ $\mathrm{M}$ trisodium citrate, $\mathrm{pH} 7.0$ ) with $30 \%$ dimethyl sulfoxide, as described by Legault-Demare et al. (19). The optimal temperature of renaturation in buffer 2 SSC$30 \%$ dimethyl sulfoxide (TorD) was calculated from De Ley and Tyjtgat's equation: TorD $=(0.51 \times \mathrm{mol} \%$ guanine plus cytosine $[\mathrm{G}+\mathrm{C}])+28.0$. The $\mathrm{G}+\mathrm{C}$ content of labeled DNA of strain 11 equaled $51.5 \mathrm{~mol} \%$. Consequently, the optimal temperature of incubation was $54.2^{\circ} \mathrm{C}$. The time of incubation was $16 \mathrm{~h}$.

Radioactivity counting was done by scintillation with $10 \mathrm{ml}$ of Bray solution (2) in vials. The rate of reassociation was calculated by the formula: (counts per minute without competitor DNA - counts per minute with heterologous DNA/counts per minute without competitor DNA - counts per minute wih homologous DNA) $\times 100$.

\section{RESULTS}

Numerical analysis of Serratia strains. The distance level for optimal delimitation of classes, calculated by the method of Verron (26), was 0.87 . According to this criterion, distinction of three main classes is then possible: $S_{A}(32$ strains), $C$ (20 strains), and $S_{B}$ (46 strains); two strains remained unclassified. Classes $S_{A}$ and $S_{B}$ can each be divided into two subclasses: $\mathrm{S}_{\mathrm{A} 1}(2$ strains) and $S_{A_{2}}$ (30 strains), and $S_{B 1}$ (13 strains) and $S_{B 2}(23$ strains) for a level equal to 0.54 .

The 92 strains selected for this study were all oxidase negative and $\beta$-galactosidase positive, attacked glucose by a fermentative pathway, and used citrate as a sole carbon source.

Classes $S_{A 1}, S_{A 2}$, and $S_{B 2}$ are identical with the three species recognized by Ewing et al. (7) within the genus Serratia-S. rubidaea, S. marcescens, and $S$. liquefaciens, respectively-and are encompassed by the single species, $S$. marcescens, recognized by Sakazaki (23) in the genus Serratia in Bergey's Manual. Class $\mathrm{S}_{\mathrm{B} 1}$ is similar to $S$. plymuthica as described by Grimont et al. (14).

The characters of the four subclasses (see Table 2) as a whole agree with those of the four species of the genus as defined by Edwards and Ewing (6), Ewing et al. (7), Johnson et al. (16), Grimont and Dulong De Rosnay (13), and Grimont et al. (14).

Phenetic study of class $C$ strains. Table 3 gives the characters of class $C$ and those of strain 11 which are conventionally determined for $E n$ terobacteriaceae. Studies on the utilization of various additional substrates which led to the classification and clustering of these bacteria were presented in a previous study (12).

Genetic study of class C strains. (i) DNADNA hybridization. The DNA relatedness of strain 11 of class $\mathrm{C}$ to 14 other isolates of this class ranged from 75 to $91 \%$; relatedness with 13 of the strains exceeded $80 \%$ (see Table 4).

Table 5 presents the DNA relatedness between strain 11 and strains belonging to different species and genera of Enterobacteriaceae.

For strains within a species, the DNA relatedness results are given in descending order. The Serratia strains were the only ones which gave rates of hybridization of over $40 \%$ with strain 11. For all the other strains, the relatedness results were close to 25 to $30 \%$.

(ii) $\mathrm{G}+\mathrm{C}$ content of DNA. The $\mathrm{G}+\mathrm{C}$ contents of the DNAs of the strains of class $C$ were studied by Ferragut et al. (8); the results are summarized in Table 6. The mean $\mathrm{G}+\mathrm{C}$ content, $50.9 \mathrm{~mol} \%$, varies greatly from the G+C content of most of the strains of the genus Serratia recorded in Table 6. However, it is close to those of strains of S. liquefaciens: $51.9 \mathrm{~mol} \%$ for ATCC 14460 (24) and $50.9 \mathrm{~mol} \%$ for the strain studied by Izard et al. (15).

\section{DISCUSSION}

The uniqueness of the class $\mathrm{C}$ strains among the Enterobacteriaceae was first suggested by Leclerc and Buttiaux (18) and was confirmed by the results of both our previous numerical taxonomy study (12) and the present investigation. Class $\mathrm{C}$ strains also represent a new entity from the genetic point of view. The DNA relatedness of the class $C$ strains ranges between 75 and $91 \%$ (Table 4). The closeness of these values is substantiated by the results (DNA reassociation, 93 to $100 \%$ ) obtained by Crosa et al. (3) with five strains of Citrobacter-like bacteria.

Table 5 presents the results of DNA-DNA reassociation between strain 11 and other Enter. obacteriaceae. Serratia is the only genus whose members showed a taxonomically significant level of relatedness to strain 11 . The very low results obtained with the strains of all the other species suggest that the strains of class $C$ should be placed in the genus Serratia.

The genus Serratia was recently studied in detail by Steigerwalt et al. (25), who determined that $S$. marcescens, $S$. liquefaciens, and $S$. rubidaea are closely related (see Table 7). For the seven strains of $S$. marcescens analyzed, the DNA relatedness varied from 84 to $100 \%$; for six strains of S. liquefaciens, it varied from 68 to $100 \%$; and for four strains of S. rubidaea, it varied 10 to $100 \%$. The relatedness between $S$. marcescens and $S$. liquefaciens is rather high, i.e., between 50 and $60 \%$.

The DNA-DNA relatedness of S. rubidaea to other Serratia species is relatively low (hybridization levels below 50\%) except for one strain, 
TABLE 1. Strains included in the phenetic study ${ }^{a}$

\begin{tabular}{rcclc}
\hline Taxon & Strain no. & Source & Culture collection no. & Name as received \\
\hline $\mathrm{S}_{\mathrm{A} 1}($ S. rubidaea $)$ & 22 & $?$ & CDC 2199-72 & S. rubidaea \\
& 91 & $?$ & $\mathrm{~S}_{36}$ &
\end{tabular}

$\mathrm{S}_{\mathrm{A} 2}$ (S. marcescens)

$\mathrm{S}_{\mathrm{B} 1}$ (S. plymuthica)

$\mathrm{S}_{\mathrm{B} 2}$ (S. liquefaciens)

$\begin{array}{lll}23 & \text { MA } & \text { CUETM 78-210 } \\ 24 & \text { MA } & \text { CUETM 78-200 } \\ 25 & \text { MA } & \text { CUETM 78-216 } \\ 26 & \text { MA } & \text { CUETM 78-211 } \\ 27 & \text { MA } & \text { CUETM 78-202 } \\ 28 & \text { MA } & \text { CUETM 78-199 } \\ 29 & \text { MA } & \text { CUETM 78-217 } \\ 30 & \text { MA } & \text { CUETM 78-215 } \\ 31 & \text { MA } & \text { CUETM 78-208 } \\ 32 & \text { MA } & \text { CUETM 78-207 } \\ 33 & \text { MA } & \text { CUETM 78-209 } \\ 34 & \text { MA } & \text { CUETM 78-213 } \\ 35 & \text { MA } & \text { CUETM 78-212 } \\ 36 & \text { MA } & \text { CUETM 78-203 } \\ 37 & \text { MA } & \text { CUETM 78-214 } \\ 38 & \text { MA } & \text { CUETM 78-198 } \\ 39 & \text { MA } & \text { CUETM 78-205 } \\ 40 & \text { MA } & \text { CUETM 78-206 } \\ 41 & \text { MA } & \text { CUETM 78-204 } \\ 42 & \text { MA } & \text { CUETM 78-201 } \\ 47 & \text { D } & \text { CUETM 78-248 } \\ & & \\ 21 & ? & \text { ATCC 13 880 } \\ 44 & ? & \text { LM 23-65 } \\ 79 & ? & \text { CUETM 78-163 } \\ 80 & ? & \text { CUETM 78-164 } \\ 86 & ? & \text { CUETM 78-165 } \\ 87 & ? & \text { CUETM 78-166 } \\ 88 & ? & \text { CUETM 78-167 } \\ 89 & ? & \text { CUETM 78-168 } \\ 90 & ? & \text { CUETM 78-169 }\end{array}$

$\begin{array}{ll}45 & \text { D } \\ 46 & \text { D } \\ 50 & \text { D } \\ 62 & \text { D } \\ 65 & \text { D } \\ 68 & \text { D } \\ 72 & \text { D } \\ 73 & \text { D } \\ 74 & \text { D } \\ 75 & ? \\ 84 & ? \\ 85 & ?\end{array}$

CUETM 78-225 CUETM 78-226 CUETM 78-224 CUETM 78-218 CUETM 78-221 CUETM 78-220 CUETM 78-219 CUETM 78-222 CUETM 78-223 B 3617 CUETM 78-170 CUETM 78-171

CUETM 78-242 CUETM 78-238 CUETM 78-244 CUETM 78-240 CUETM 78-229 CUETM 78-246 CUETM 78-230 CUETM 78-236 CUETM 78-243 CUETM 78-241 CUETM 78-239
Original isolate Original isolate Original isolate Original isolate Original isolate Original isolate Original isolate Original isolate Original isolate Original isolate Original isolate Original isolate Original isolate Original isolate Original isolate Original isolate Original isolate Original isolate Original isolate Original isolate Original isolate

S. marcescens $S$. marcescens Serratia sp. Serratia sp. Serratia sp. Serratia sp. Serratia sp. Serratia sp. Serratia sp.

Original isolate Original isolate Original isolate Original isolate Original isolate Original isolate Original isolate Original isolate Original isolate S. plymuthica Serratia sp. Serratia sp.

Original isolate Original isolate Original isolate Original isolate Original isolate Original isolate Original isolate Original isolate Original isolate Original isolate Original isolate 
TABLE 1. (continued)

\begin{tabular}{|c|c|c|c|c|}
\hline Taxon & Strain no. & Source & Culture collection no. & Name as received \\
\hline & $\begin{array}{l}60 \\
61 \\
63 \\
64 \\
66 \\
67 \\
69 \\
70 \\
71 \\
76\end{array}$ & $\begin{array}{l}\text { D } \\
D \\
D \\
D \\
D \\
D \\
D \\
D \\
D \\
\text { So }\end{array}$ & $\begin{array}{l}\text { CUETM } 78-245 \\
\text { CUETM } 78-237 \\
\text { CUETM } 78-234 \\
\text { CUETM } 78-235 \\
\text { CUETM } 78-228 \\
\text { CUETM } 78-247 \\
\text { CUETM } 78-231 \\
\text { CUETM } 78-197 \\
\text { CUETM } 78-232 \\
\text { CUETM } 78-233\end{array}$ & $\begin{array}{l}\text { Original isolate } \\
\text { Original isolate } \\
\text { Original isolate } \\
\text { Original isolate } \\
\text { Original isolate } \\
\text { Original isolate } \\
\text { Original isolate } \\
\text { Original isolate } \\
\text { Original isolate } \\
\text { Original isolate }\end{array}$ \\
\hline & $\begin{array}{l}77 \\
78 \\
81 \\
92\end{array}$ & $\begin{array}{l}? \\
? \\
? \\
?\end{array}$ & $\begin{array}{l}\text { CUETM 78-172 } \\
\text { CUETM 78-173 } \\
\text { CUETM 78-174 } \\
\text { ATCC } 14460\end{array}$ & $\begin{array}{c}\text { Serratia sp. } \\
\text { Serratia sp. } \\
\text { Serratia sp. } \\
\text { E. liquefaciens }\end{array}$ \\
\hline Class C & $\begin{array}{c}1(33)^{b} \\
5(65) \\
6(80) \\
7(81) \\
8(89) \\
9(92) \\
10(93) \\
11(95) \\
12(98) \\
13(99) \\
14(100) \\
15(101) \\
16(102) \\
17(104) \\
18(105) \\
19(106) \\
20(107) \\
2(40) \\
3(45) \\
4(52)\end{array}$ & $\begin{array}{l}\text { Se } \\
\text { Su } \\
\text { D } \\
\text { D } \\
D \\
D \\
D \\
D \\
D \\
D \\
D \\
D \\
\text { D } \\
D \\
D \\
D \\
D \\
D \\
\text { Do } \\
\text { So } \\
\text { So }\end{array}$ & 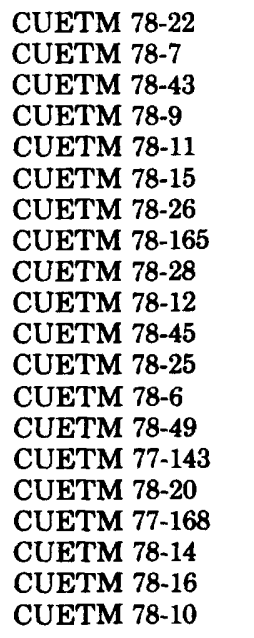 & $\begin{array}{l}\text { Original isolate } \\
\text { Original isolate } \\
\text { Original isolate } \\
\text { Original isolate } \\
\text { Original isolate } \\
\text { Original isolate } \\
\text { Original isolate } \\
\text { Original isolate } \\
\text { Original isolate } \\
\text { Original isolate } \\
\text { Original isolate } \\
\text { Original isolate } \\
\text { Original isolate } \\
\text { Original isolate } \\
\text { Original isolate } \\
\text { Original isolate } \\
\text { Original isolate } \\
\text { Original isolate } \\
\text { Original isolate } \\
\text { Original isolate }\end{array}$ \\
\hline Unclassified & $\begin{array}{l}82 \\
83\end{array}$ & $?$ & $\begin{array}{l}\text { CUETM 78-175 } \\
\text { CUETM 78-176 }\end{array}$ & $\begin{array}{l}\text { Serratia sp. } \\
\text { Serratia sp. }\end{array}$ \\
\hline
\end{tabular}

${ }^{a}$ Abbreviations: B, J. Brisou, University of Poitiers, France; CDC, Center for Disease Control, Atlanta, Ga.; CUETM, Collection Unité d'Ecotoxicologie Microbienne, Villeneuve d'Ascq, France; LM, L. Le Minor, Institut Pasteur, Paris, France; D, drinking water; MA, medical analysis; Se, sewage; So, unpolluted soils; Su, surface water.

${ }^{b}$ Numbers in parentheses are corresponding strain numbers of these strains used in a previous study (12).

which is $52 \%$ related to a strain of $S$. liquefa. ciens.

Some of the strains of the group of Citrobacter-like bacteria, four of which were studied here, were previously (25) assigned to one of three species of the genus Serratia. The DNA relatedness values of these bacteria ranged from 51 to $57 \%$ with $S$. marcescens, from 46 to $52 \%$ with $S$. liquefaciens, and from 41 to $44 \%$ with $S$. rubidaea. These values are very close to those obtained between species of the genus Serratia. The results of our determination of the DNA relatedness of the species $S$. marcescens (7 strains), S. liquefaciens (2 strains), S. plymuthica (2 strains), and $S$. rubidaea (3 strains) to labeled DNA of strain 11 of class $C$ are given in Table 5. The data indicate a relationship of class C strains to the genus Serratia.

Two of the three analyzed strains of $S$. rubi. daea (S. rubidaea CDC 934-72 and S. marinorubra (S. rubidaea) S 36) show very low hybridization levels with strain $11-24$ and $30 \%$, respectively. These data confirm the low level of relatedness of S. rubidaea with the other species of the genus. The identities of these two collection strains might also have to be revised. Except 


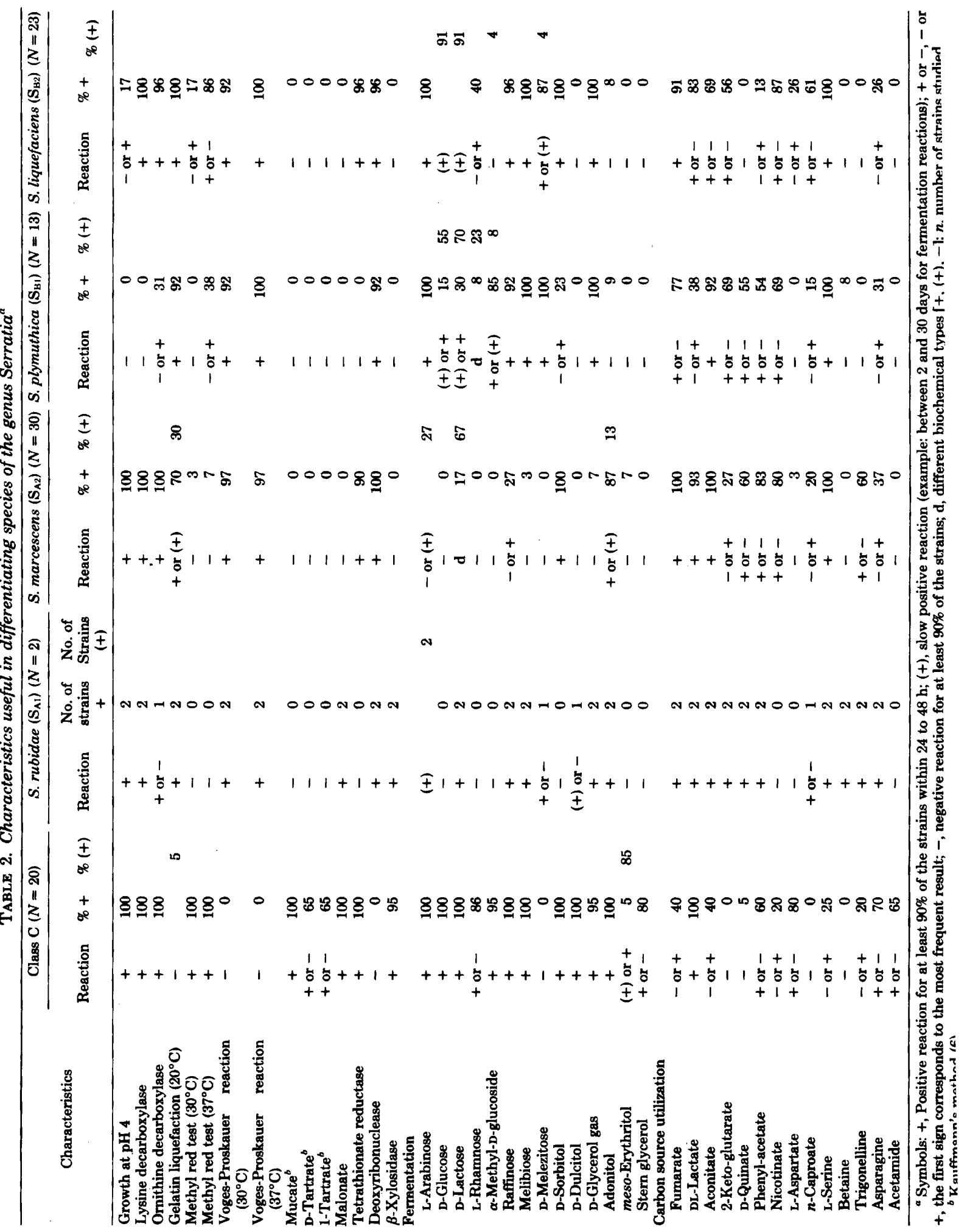


TABLE 3. Phenetic characterization of class $C$ strains

\begin{tabular}{|c|c|c|c|c|}
\hline \multirow[t]{2}{*}{ Characteristic } & \multicolumn{3}{|c|}{$\begin{array}{c}\text { Class C } \\
(N=20)\end{array}$} & \multirow{2}{*}{$\begin{array}{r}\text { Strain } 11(= \\
\text { ATCC 29844) }\end{array}$} \\
\hline & Reaction $^{a}$ & $\%+$ & $\%(+)$ & \\
\hline Growth at $4^{\circ} \mathrm{C}$ & +4 & 100 & & + \\
\hline Growth at $41^{\circ} \mathrm{C}$ & - & 0 & & - \\
\hline Growth at $44.5^{\circ} \mathrm{C}$ & - & 0 & & - \\
\hline Motility at $30^{\circ} \mathrm{C}$ & + & 100 & & + \\
\hline Motility at $37^{\circ} \mathrm{C}$ & + & 100 & & + \\
\hline $\mathrm{KCN}$ & + & 95 & & + \\
\hline Lysine decarboxylase & + & 100 & & + \\
\hline Arginine dihydrolase & - & 0 & & - \\
\hline Ornithine decarboxylase & + & 100 & & + \\
\hline Gelatin liquefaction $\left(20^{\circ} \mathrm{C}\right)$ & - & & 5 & - \\
\hline Urease & - & 0 & & - \\
\hline Indole & - & 0 & & - \\
\hline Methyl red test $\left(30^{\circ} \mathrm{C}\right)$ & + & 100 & & + \\
\hline Methyl red test $\left(37^{\circ} \mathrm{C}\right)$ & + & 100 & & + \\
\hline Voges-Proskauer reaction $\left(30^{\circ} \mathrm{C}\right)$ & - & 0 & & - \\
\hline Voges-Proskauer reaction $\left(30^{\circ} \mathrm{C}\right)$ & - & 0 & & - \\
\hline Citrate (Simmons) $30^{\circ} \mathrm{C}$ & + & 100 & & + \\
\hline Citrate (Simmons) $37^{\circ} \mathrm{C}$ & + & 100 & & + \\
\hline Malonate & + & 100 & & + \\
\hline D-Tartrate ${ }^{b}$ & + or - & 65 & & + \\
\hline 1-Tartrate ${ }^{b}$ & + or - & 65 & & + \\
\hline$m$-Tartrate ${ }^{b}$ & - & 0 & & - \\
\hline Mucate $^{b}$ & + & 100 & & + \\
\hline Jordan tartrate & + & 100 & & + \\
\hline Phenylalanine deaminase & - & 0 & & - \\
\hline Nitrate to nitrite & + & 100 & & + \\
\hline $\mathrm{H}_{2} \mathrm{~S}$ production & - & 0 & & - \\
\hline Tetrathionate reductase & + & 100 & & + \\
\hline Tween-esterase & + & 100 & & + \\
\hline Deoxyribonuclease & - & 0 & & - \\
\hline Chitinolysis & - & 0 & & - \\
\hline$\beta$-Galactosidase & + & 100 & & + \\
\hline$\beta$-Xylosidase & + & 95 & & + \\
\hline \multicolumn{5}{|l|}{ Fermentation } \\
\hline L-Arabinose & + & 100 & & + \\
\hline D-Xylose & + or - & 70 & & + \\
\hline D-Ribose & + & 100 & & + \\
\hline Maltose & + & 100 & & + \\
\hline D-Glucose (gas) & + & 100 & & + \\
\hline D-Lactose & + & 100 & & + \\
\hline D-Galactose & + & 100 & & + \\
\hline L-Rhamnose & + or - & 80 & & + \\
\hline D-Mannose & + & 100 & & + \\
\hline D-Fructose & + & 100 & & + \\
\hline$\alpha$-Methyl D-glucoside & + & 95 & & + \\
\hline D-Trehalose & + & 100 & & + \\
\hline Raffinose & + & 100 & & + \\
\hline L-Sorbose & - & 0 & & - \\
\hline Melibiose & + & 100 & & + \\
\hline D-Melezitose & - & 0 & & - \\
\hline D-Sucrose & $(+)$ or - & 20 & 80 & +7 \\
\hline D-Mannitol & + & 100 & & + \\
\hline D-Dulcitol & + & 100 & & +2 \\
\hline meso-Inositol & + & 95 & & + \\
\hline D-Cellobiose (acid) & $(+)$ & & 95 & +6 \\
\hline D-Cellobiose (gas) & $(+)$ & & 95 & +5 \\
\hline D-Glycerol (gas) & + & 95 & & + \\
\hline Adonitol & + & 100 & & + \\
\hline meso-Erythritol & $(+)$ or + & 5 & 85 & +5 \\
\hline Salicin & + & 100 & & + \\
\hline Inulin & - or $(+)$ & & 20 & - \\
\hline Glycogen & $(+)$ or - & & 60 & +3 \\
\hline Esculin hydrolysis & + & 100 & & + \\
\hline
\end{tabular}

${ }^{a}$ Symbols as in Table 2. Numbers after symbols indicate number of days for reaction to take place.

${ }^{b}$ Kauffmann's method (6). 
TABLE 4. DNA relatedness of 14 other strains of class $C$ to strain 11

\begin{tabular}{cc}
\hline $\begin{array}{c}\text { Class C strain } \\
\text { (source of unlabeled DNA) }\end{array}$ & $\begin{array}{c}\text { \% Binding by competition } \\
\text { with strain 11 DNA }\end{array}$ \\
\hline 11 & 100 \\
8 & 91 \\
7 & 91 \\
4 & 90 \\
6 & 90 \\
12 & 89 \\
21 & 89 \\
9 & 88 \\
10 & 88 \\
2 & 87 \\
15 & 87 \\
18 & 85 \\
16 & 84 \\
20 & 81 \\
1 & 75 \\
\hline
\end{tabular}

for these two strains, the data on genetic information are in very good agreement. The relatedness between strain 11 and the other bacteria of the genus Serratia is between 43 and 57\%, i.e., within the range of values for the recognized species of the genus. These results justify for class $\mathrm{C}$ the status of species within the genus Serratia.

A numerical analysis of the phenetic characters of the class $C$ strains reveals the uniqueness of these strains with regard to the taxa identified as $S$. marcescens, S. liquefaciens, S. plymuthica, and $S$. marinorubra. The taxonomic distance between class $\mathrm{C}$ and the pairs $S$. liquefaciens$S$. plymuthica and S. marcescens-S. rubidaea is equal to the distance $(0.40)$ between these pairs. The species status of class $C$ is confirmed by the results of both the genetic analysis and the phenetic study.

The strains of class $C$ can only be located within the genus Serratia in spite of the discrepancies previously mentioned. Some of the characters of class $C$ strains do not agree with the definition of the genus: Voges-Proskauer reaction negative, deoxyribonuclease not produced, gelatin not liquefied, and fermentation of rhamnose, arabinose, and raffinose. This necessitates an amendment of the definition of the genus Serratia. Characters useful in differentiating class C strains from strains of the named species of Serratia recognized here are given in Table 2.

The name Serratia fonticola (fon.ticó.la. L.n. fons, fontis: spring, fountain; L. suffix cola: dweller; M.L.n. fonticola: spring dweller) is proposed for this new species of bacteria, many strains of which have been isolated from well waters and springs. Strain 11 (ATCC 29844) is the type strain of the species.
Description of S. fonticola (based on 20 strains). Gram-negative, rod-shaped cells (0.5 by $30 \mu \mathrm{m}$ ) which are motile and peritrichous.

Growth occurs on nutrient agar at 30 and $37^{\circ} \mathrm{C}$ but not at $41^{\circ} \mathrm{C}$; growth occurs at $4^{\circ} \mathrm{C}$.

All of the strains are positive for: citrate (Simmons), malonate, tartrate (Jordan), and mucate utilization; nitrate reduction to nitrite; lysine and ornithine decarboxylase production; production of tetrathionate reductase and Tween-esterase; production of $\beta$-galactosidase and $\beta$-xylosidase; and esculin hydrolysis.

All of the strains are negative for the production of indole, acetoin, $\mathrm{H}_{2} \mathrm{~S}$, arginine dihydrolase, gelatinase, urease, phenyl alanine deaminase, and deoxyribonuclease.

Eight to $100 \%$ of the strains are positive within 24 to $48 \mathrm{~h}$ for the fermentation of L-arabinose, D-ribose, maltose, D-glucose, D-lactose, D-galactose, L-rhamnose, D-mannose, D-fructose, $\alpha$ methyl-D-glucoside, D-trehalose, raffinose, melibiose, D-sucrose, D-mannitol, D-dulcitol, mesoinositol, D-glycerol, adonitol, and salicin.

Eighty to $100 \%$ of the strains were negative within 30 days for the fermentation of $L$-sorbose, D-melezitose, and inulin.

Carbon source utilization: Eighty to $100 \%$ of the strains utilize (within 5 days) the following as sole sources of carbon: L-arabinose, D-ribose, L-rhamnose, D-fructose, D-galactose, D-glucose, D-mannose, D-maltose, D-trehalose, gluconate, salicin, D-glycerol, meso-erythritol, adonitol, Dmannitol, D-dulcitol, meso-inositol, $D$-sorbitol, DL-lactate, DL-glycerate, pyruvate, citrate, succinate, $L$ - $\alpha$-alanine, $D$ - $\alpha$-alanine, $L$-aspartate, $L$ glutamate, L-proline, L-histidine, and putrescine.

Eighty to $100 \%$ of the strains do not utilize (within 5 days) the following as sole sources of carbon: D-arabinose, D-fucose, D-cellobiose, Dsucrose, inulin, ethanol, methanol, $n$-propanol, iso-propanol, geraniol, 2,3-butylene-glycol, ethylene-glycol, propylene-glycol, propionate, DL-3hydroxy-butyrate, D-tartrate, L-tartrate, $m$-tartrate, citraconate, itaconate, oxalate, pimelate, suberate, azelate, glycolate, levulinate, 2-ketoglutarate, mesaconate, glutarate, sebacate, salicylate, adipate, butyrate, iso-butyrate, $n$-valerate, iso-valerate, $n$-caproate, heptanoate, pelargonate, caprate, benzoate, $p$-OH-benzoate, D-mandelate, $\mathrm{L}$-mandelate, phtalate, iso-phtalate, terephtalate, phenol, benzyl-formate, glycine, $\beta$-alanine, L-leucine, L-isoleucine, L-valine, L-lysine, L-arginine, L-citrulline, L-threonine, L-methionine, DL-2-amino-butyrate, DL-3-amino-butyrate, DL-4-amino-butyrate, 5-amino-valerate, 2amino-benzoate, 4-amino-benzoate, D-tryptophane, histamine, spermine, tryptamine, amylamine, ethanolamine, butylamine, benzylamine, diphenylamine, urea, urate, sarcosine, betaine, 
TABLE 5. DNA homogeneity of Citrobacter-like strains and class $C$ strains and DNA relatedness of reference strains of these taxa to members of the family Enterobacteriaceae

\begin{tabular}{|c|c|c|}
\hline Source of unlabeled DNA ${ }^{a}$ & $\begin{array}{c}\text { Citrobacter-like strain } \\
4556-71(\% \text { binding at } \\
\left.60^{\circ} \mathrm{C}\right)^{b}\end{array}$ & $\begin{array}{l}\text { Class } C \text { strain } 11 \text { (\% bind- } \\
\text { ing by competition) }\end{array}$ \\
\hline $\begin{array}{l}\text { Citrobacter-like strain } 4556-71 \\
\text { Citrobacter-like strains }(5)^{c} \\
\text { Class C strain } 11 \\
\text { Class C strains }(14)^{c}\end{array}$ & $\begin{array}{c}100 \\
93-96\end{array}$ & $\begin{array}{c}100 \\
75-91\end{array}$ \\
\hline $\begin{array}{l}\text { Serratia marcescens LM 1-63 } \\
\text { S. marcescens LM } 23-65 \\
\text { S. marcescens subsp. kiliensis ATCC } 8101 \\
\text { S. marcescens ATCC } 13880 \\
\text { S. marcescens CDC } 868-57 \\
\text { S. marcescens SM6-W2 } \\
\text { S. marcescens strain } 37^{d} \\
\text { S. liquefaciens LM } 3-70 \\
\text { S. liquefaciens strain } 70^{d} \\
\text { S. plymuthica strain } 3617 \text { B } \\
\text { S. plymuthica strain } 62^{d} \\
\text { S. rubidaea CDC } 2199-72 \\
\text { S. rubidaea CDC } 934-72 \\
\text { S. marinorubra S36 }\end{array}$ & 47 & $\begin{array}{l}57 \\
54 \\
53 \\
49 \\
47 \\
\\
42 \\
43 \\
40 \\
48 \\
45 \\
59 \\
24 \\
30\end{array}$ \\
\hline Escherichia coli K-12 1 UW & 25 & 24 \\
\hline $\begin{array}{l}\text { Citrobacter freundii strains } \\
\text { C. freundii CUETM 77-166 } \\
\text { C. diversus strains }\end{array}$ & $\begin{array}{l}25-30 \\
28-30\end{array}$ & 18 \\
\hline $\begin{array}{l}\text { Levinea malonatica CDC } 25408 \\
\text { L. amalonatica strains }\end{array}$ & $\begin{array}{c}27 \\
27-28\end{array}$ & 26 \\
\hline $\begin{array}{l}\text { Enterobacter cloacae CDC 1347-71 } \\
\text { E. aerogenes CDC } 1627-66 \\
\text { E. agglomerans CH } 103 \\
\text { Escherichia coli subsp. adecarboxylata ATCC } 1783\end{array}$ & $\begin{array}{l}28 \\
28 \\
25\end{array}$ & 18 \\
\hline Hafnia alvei CDC 4360-67 & 27 & \\
\hline $\begin{array}{l}\text { Klebsiella rhinoscleromatis CDC } 895-68 \\
K . \text { pneumoniae strain } 2 \\
K . \text { pneumoniae ATCC } 13882 \\
K . \text { ozaenae CDC } 276-71 \\
\text { K. oxytoca ATCC } 13182\end{array}$ & 31 & $\begin{array}{l}32 \\
27 \\
24 \\
18\end{array}$ \\
\hline $\begin{array}{l}\text { Erwinia dissolvens ATCC } 23373 \\
\text { E. amylovora EA } 178 \\
\text { Pectobacterium carotovorum ATCC } 495\end{array}$ & $\begin{array}{l}22 \\
24\end{array}$ & 24 \\
\hline $\begin{array}{l}\text { Salmonella typhimurium LT2 } \\
\text { S. arizonae CDC } 62 \\
\text { S. houtenae CIS } 498\end{array}$ & 22 & $\begin{array}{r}19 \\
5\end{array}$ \\
\hline $\begin{array}{l}\text { Shigella dysenteriae A1 WRAIR } \\
\text { S. sonnei ATCC } 9290 \\
\text { S. flexneri ATCC } 12661 \\
\text { S. boydii } 1 \text { DP Wol. Paris }\end{array}$ & & $\begin{array}{l}36 \\
27 \\
22 \\
21\end{array}$ \\
\hline Edwardsiella tarda CDC 1795-62 & 23 & \\
\hline $\begin{array}{l}\text { Proteus vulgaris ATCC } 13315 \\
P . \text { morganii LM } 11-70 \\
P . \text { mirabilis ATCC } 9240 \\
P . \text { stuartii LM } 1-70 \\
P . \text { alcalifaciens ATCC } 13159\end{array}$ & & $\begin{array}{l}18 \\
16 \\
15 \\
14 \\
10\end{array}$ \\
\hline $\begin{array}{l}\text { Yersinia pseudotuberculosis LM 48-1 } \\
\text { Y. enterocolitica } 377\end{array}$ & & $\begin{array}{l}5 \\
0\end{array}$ \\
\hline
\end{tabular}

${ }^{a}$ Abbreviations: B, J. Brisou, University of Poitiers, France; CDC, Center for Disease Control, Atlanta, Ga.; CIS, Centre International des Salmonella, Institut Pasteur, Paris, France; CUETM, Collection Unité Ecotoxicologie Microbienne, Villeneuve d'Ascq, France; LM, L. Le Minor, Institut Pasteur, Paris; UW, University of Washington, Seattle, Wash.; WRAIR, Walter Reed Army Institute of Research, Washington, D.C.

${ }^{b}$ Crosa et al. (3).

c Number of strains.

${ }^{d}$ Strain number as used in this study. 
TABLE 6. $G+C$ content of the DNA of class $C$ strains and of Serratia strains

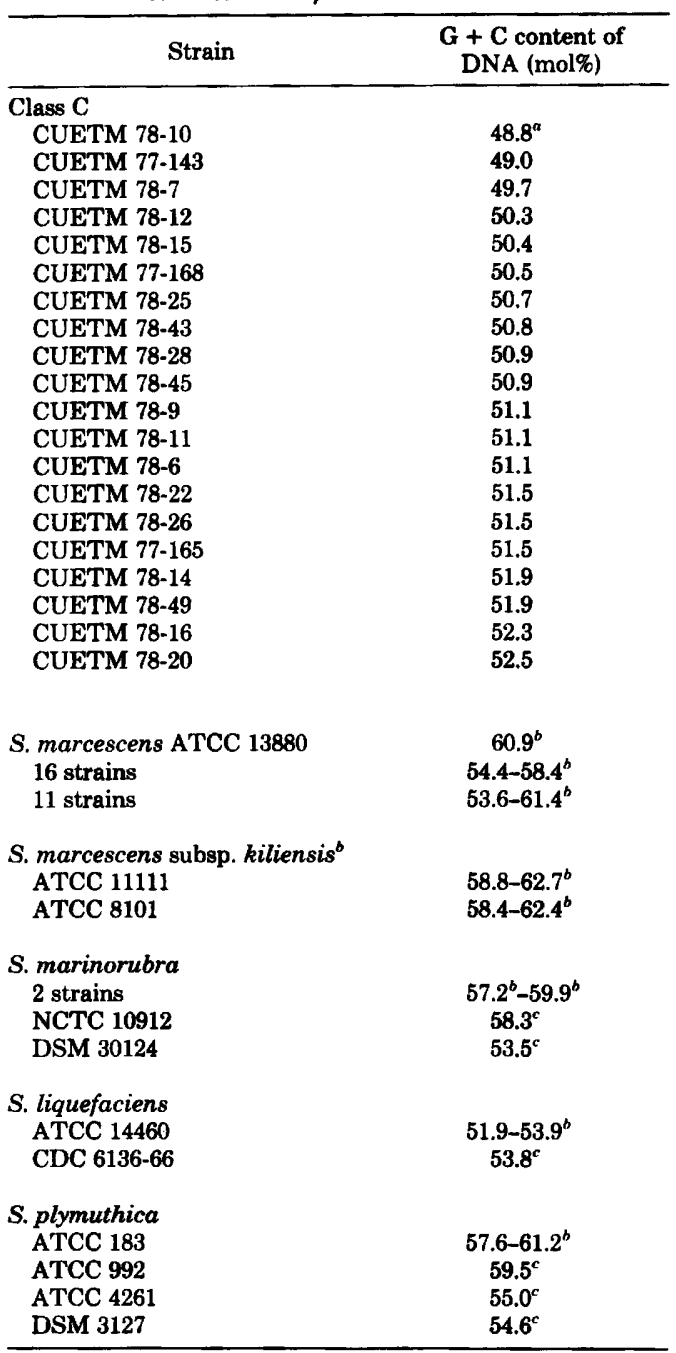

${ }^{a}$ Data on all class $\mathrm{C}$ strains from reference 8.

${ }^{b}$ Data from reference 17.

${ }^{c}$ Data from reference 14.

creatine, hippurate, pantothenate, nicotinate, trigonelline, naphthalene, dodecane, and hexadecane.

Within the genus Serratia Bizio, we recognize the following species: (i) Serratia marcescens Bizio (type species), (ii) Serratia liquefaciens (Grimes and Hennerty) Bascomb et al. (1), (iii) Serratia rubidaea (Stapp) Ewing et al. (7), and (iv) Serratia fonticola sp. nov.

In addition to these Grimont et al. (14) recognize the species Serratia plymuthica (Bacterium plymuthicum (Fisher) Lehmann and Neumann).
TABLE 7. DNA homologies among $S$. marcescens, $S$. liquefaciens, and $S$. rubidaea strains and strains of the Citrobacter-like group ${ }^{a}$

\begin{tabular}{lccc}
\hline \multicolumn{1}{c}{ Taxon } & $\begin{array}{c}\text { S. marces. } \\
\text { cens }\end{array}$ & $\begin{array}{c}\text { S. liquefa- } \\
\text { ciens }\end{array}$ & $\begin{array}{c}\text { S. rubi- } \\
\text { daea }\end{array}$ \\
\hline $\begin{array}{l}\text { S. marcescens }(7 \\
\text { strains) }\end{array}$ & $84-100^{b}$ & $51-60$ & $44-53$ \\
$\begin{array}{l}\text { S. liquefaciens }(6 \\
\text { strains) }\end{array}$ & $52-63$ & $68-100$ & $41-47$ \\
$\begin{array}{l}\text { S. rubidaea (4 } \\
\text { strains) }\end{array}$ & $47-51$ & $40-49$ & $70-100$ \\
$\begin{array}{l}\text { Citrobacter-like (4 } \\
\text { strains) }\end{array}$ & $51-57$ & $46-52$ & $41-44$ \\
\hline
\end{tabular}

${ }^{a}$ Data from Steigerwalt et al. (25).

${ }^{b}$ Percent binding at $60^{\circ} \mathrm{C}$.

\section{ACKNOWLEDGMENTS}

We thank D.J. Brenner, W.H. Ewing, M. Véron, and P.A.D. Grimont, who provided most of the collection strains used in this study. We thank Annie Bernigaud, Nicole Marquis, and Etienne Dewailly for their technical collaboration.

\section{REPRINT REQUESTS}

Address reprint requests to: Dr. $\mathrm{H}$. Leclerc, Institut Pasteur de Lille, Institut National de la Santé et de la Recherche Medicale U 146, Domaine du Certia, BP 15 France.

\section{LITERATURE CITED}

1. Bascomb, S., S. P. Lapage, and H. A. Curtis. 1971 Numerical classification of the tribe Klebsielleae. J. Gen. Microbiol. 66:279-295.

2. Bray, G. A. 1960. A simple efficient liquid scintillation for counting aqueous solutions in a liquid scintillation counter. Anal. Biochem. 1:279-285.

3. Crosa, J. M., A. G. Steigerwalt, G. R. Fanning and D. J. Brenner. 1974. Polynucleotide sequence divergence in the genus Citrobacter. J. Gen. Microbiol. 83: 271-282.

4. Delabre, M., A. Bianchi, and M. Véron. 1973. Etude critique des méthodes de taxonomie numérique. Application à une classification des bactéries aquicoles. Ann. Microbiol. (Inst. Pasteur) 124A:489-506.

5. De Ley, J., and R. Tyjtgat. 1970. Evaluation of membrane filter methods for DNA-DNA hybridization. Antonie van Leeuwenhoek, J. Microbiol. Serol. 36:461474.

6. Edwards, P. R., and W. H. Ewing. 1972. Identification of Enterobacteriaceae, 3rd ed. Burgess Publishing Co. Minneapolis.

7. Ewing, W. H., B. R. Davis, M. A. Fife, and E. F. Lessel. 1973. Biochemical characterization of Serratia liquefaciens (Grimes and Hennerty) Bascomb et al. (formerly Enterobacter liquefaciens) and Serratia rub. idaea (Stapp) comb. nov. and designation of type and neotype strains. Int. J. Syst. Bacteriol. 23:217-225.

8. Ferragut, C., F. Gavini, D. Izard, and H. Leclerc. 1978. Etude du \% GC dans un groupe d'entérobactéries $\mathrm{H}_{2} \mathrm{~S}^{-}$apparentées au genre Citrobacter. Can. J. Microbiol. 24:473-479.

9. Ferragut, C., and H. Leclerc. 1976. Etude comparative des méthodes de détermination du Tm de l'ADN bactérien. Ann. Microbiol. (Inst. Pasteur) 127 A:223-235.

10. French, C. S., and H. W. Milner. 1955. Disintegration of bacteria and small particles by high pressure extension. Methods Enzymol. 1:64-67.

11. Gavini, F., C. Ferragut, B. Lefebvre, and H. Leclerc. 1976. Etude taxonomique d'entérobactéries appartenant ou apparentées au genre Enterobacter. Ann. Microbiol. (Inst. Pasteur) 127B:317-335. 
12. Gavini, F., B. Lefebvre, and H. Leclerc. 1976. Positions taxonomiques d'entérobactéries $\mathrm{H}_{2} \mathrm{~S}^{-}$par rapport au genre Citrobacter. Ann. Microbiol. (Inst. Pasteur) 127A:275-295.

13. Grimont, P. A. D., and H. L. C. Dulong de Rosnay. 1972. Numerical study of 60 strains of Serratia. J. Gen. Microbiol. 72:259-268.

14. Grimont, P. A. D., F. Grimont, H. L. C. Dulong de Rosnay, and P. H. A. Sneath. 1977. Taxonomy of the genus Serratia. J. Gen. Microbiol. 98:39-66.

15. Lzard, D., C. Ferragut, F. Gavini, and H. Leclerc. 1978. Variations of the moles percent guanine plus cytosine within a group of Enterobacteriaceae belonging or related to the genus Enterobacter. Int. J. Syst. Bacteriol. 28:449-452.

16. Johnson, P., R. Colwell, R. Sakazaki, and R. Tamura. 1975. Numerical taxonomy study of the Enterobacteriaceae. Int. J. Syst. Bacteriol. 25:12-37.

17. Laskin, A. I., and H. A. Lechevalier. 1973. Microbial competition, p. 585-691. In Handbook of microbiology, vol. 2. CRC Press.

18. Leclerc, H, and R. Buttiaux. 1965. Les Citrobacter. Ann. Inst. Pasteur Lille 16:67-74.

19. Legault-Demare, J., B. Desseaux, T. Heymans, S. Seror, and G. P. Ress. 1967. Studies on hybrid molecules of nucleic acids. I. DNA-DNA hybrids on nitrocellulose filters. Biochem. Biophys. Res. Commun. 28: 550-557.
20. Mandel, M., and J. Marmur. 1968. Use of ultraviolet absorbance-temperature profile for determining the guanine plus cytosine content of DNA. Methods Enzymol. 12B:195-206.

21. Marmur, J. 1961. A procedure for isolation of desoxyribonucleic acid from microorganisms. J. Mol. Biol. 3: 208-218.

22. Mossel, D. A. A., and H. Swart. 1960. The rapid tentative recognition of psychrotrophic types among Enterobacteriaceae isolated from foods. J. Appl. Bacteriol. 23: $185-188$.

23. Sakazaki, R. 1974. Genus IX. Serratia Bizio 1823, p. 326. In R.E. Buchanan and N.E. Gibbons (ed.), Bergey's manual of determinative bacteriology, 8 th ed. The Williams and Wilkins Co., Baltimore.

24. Starr, M. P., and M. Mandel. 1969. DNA base composition and taxonomy of phytopathogenic and other enterobacteria. J. Gen. Microbiol. 56:113-123.

25. Steigerwalt, A. G., G. R. Fanning, M. A. Fife-Asbury, and D. J. Brenner. 1976. DNA relatedness among species of Enterobacter and Serratia. Can. J. Microbiol. 22:121-137.

26. Véron, M. 1974. Sur un critère de calcul du meilleur niveau de coupure du dendrogramme de classification hiérarchique. Ann. Microbiol. (Inst. Pasteur) 125B:2944. 